\title{
HUMAN RIGHTS AND THE POLICING OF DISORDER IN SOUTH AFRICA: CHALLENGES AND FUTURE DIRECTIONS
}

\author{
Shaka Yesufu \\ Department of Research and Development \\ University of Limpopo \\ Turfloop, Sovenga, Republic of South Africa \\ Shakazulu17@yahoo.co.uk
}

\begin{abstract}
Unarguably, the South African Police during the apartheid era was characterised by brutality and state repression, including the political executions of several South African citizens who dared oppose the apartheid regime. The post-apartheid era has also witnessed deaths of citizens at the hands of the police during demonstrations, demanding better service delivery, higher wages, improved working conditions, and an end to marginalisation and poverty. The author presents some cases of police human rights violations concerning policing citizen's protests. This is a qualitative study, relying on extensive literature review by previous researchers. The findings of this study are: The South Africa Police Service continues to violate citizen's right to protest, which is enshrined in the Republic of South Africa's constitution under chapter 2 "Bill of Rights" and other international legal jurisprudence. The South African police have failed to perform their duties professionally and effectively when it comes to policing protests. Crown management remains an elusive issue both during the apartheid and post-apartheid eras. The author recommends a demilitarization of the police consistent with the South African government policy recommendation, found in the National Development Plan 2030.

Keywords: public disorder, reasonable force, excessive force, lethal or deadly force, protesters, human rights.
\end{abstract}

DOI: 10.21303/2504-5571.2021.001861

\section{Introduction}

South African citizens have witnessed twenty-six years of democracy; during this time, the role of the South African Police Service has become very important and has been subject to closer scrutiny by citizens. The use of firearms by the South African police against defenceless citizens during public protests is becoming a common occurrence and is discomforting for most South Africans, especially when citizens are killed by the police during such public protests. One is tempted to ask what type of public order policing model the South African Police Service is deploying. Some critiques have argued that the SAPS public order units were originally built on the Belgian Police model, which encourages confrontation, and during the world cup in South Africa, we observed a shift towards the French policing model during the 2010 FIFA World Cup [1, 2].

The South Africa Human Rights Commission is an institution, established under section 181 of the Republic of South Africa Act 108 of 1996 with the following objectives:

- Promote respect for human rights

- Promote the protection, development and attainment of human rights and

- Monitor and assess the observance of human rights in South Africa.

Police brutality arising from the policing of disorder has a long history in South Africa [3]. One can safely argue that the unlawful violence, occurring today in South Africa, is not new and is not very different from the police violence, inherited from the apartheid era. It can be argued, that the true meaning of Human Rights has not been completely understood by the South African Police Service and organisers of protests. Had the police and organisers of protests in South Africa truly understood the importance of human rights and the transition from apartheid violence to the post-apartheid democratic era, as they claimed, the killing of 34 miners at Marikana in August 2012 by the police would not have happened, and Andries Tatane would not have been killed during the service delivery protest in 2011 in Ficksburg Free State.

Finally, the author presents some of the recent killings of protesters by the police in South Africa. The author invites the South African government and the international community to inter- 
vene in these extra-judicial and unlawful killings. The author examines each of these unfortunate incidents, highlighted above, as a few of the case studies, informing the study.

\section{1. Marikana incidence}

On Monday $13^{\text {th }}$ of August 2012, there had been some violent clashes between striking miners and security authorities at Lonmin plant Marikina North West Province South Africa. Miners were demanding better pay. During the first day of clashes, four people lost their lives. Over the $14^{\text {th }}$ and $15^{\text {th }}$ August 2012, the SAPS tried to resolve the matter through negotiations. The SAPS members, involved in negotiating, were undermined by their provincial commissioner who discourages Lonmin from negotiating, thereby reinforcing Lonmin's intransigence [4-6]. Three days after, on $16^{\text {th }}$ August 2012, the police reinforced with full deployment, 34 miners were gunned down, 34 miners at close shooting proximity. The killing of 34 miners caused mayhem and immeasurable trauma to the families of those who were killed and the communities they came from [3, 7]. The author argues that violent police officers who unlawfully kill innocent citizens must be made to face justice $[8,9]$. This would send a clear message to errant police officers that they will no longer enjoy immunity from prosecution by hiding behind their uniforms. Proper accountability is needed to restore sanity and to foster respect and trust for the police in South Africa. However, there is still a widely held belief amongst police officers in South Africa that respect for human rights impedes crime prevention [10]

The Constitution of the Republic of South Africa (Section 205 sub-section (3)) clearly defines the functions of the police as follows:

- To prevent, combat, and investigate crime,

- To maintain law and order,

- To protect and secure the inhabitants of the Republic and their property, and to uphold and enforce the law.

In the first part of this article, the researcher explores the citizen's right to demonstrate, enshrined in international laws and South Africa's domestic laws.

In the second part of the article, the researcher examines various incidents, in which the South African Police Service has violated the fundamental human rights of citizens during protests.

In the third part of the article, the researcher looks at other police forces in different parts of the world (specifically, the United Kingdom and Canada) to draw examples of some best practices about how public order incidents should be policed with minimal casualties.

In the fourth part of the article, the researcher explores the concept of police culture as a stumbling block to the police's ability to comprehend the value of respect for the human rights of citizens.

Criminal Procedure and Evidence Act 51 of 1977 as Amended

Sections 49(1) and (2) of the Act empower the police to use lethal force in circumstances where a suspect is attempting to flee or posing a danger or a threat to life. The object and purpose of these sections are to ensure the safety and security of all persons.

\section{2. The Regulation of Gatherings Act 205 of 1993}

"Gathering" is defined under the Act as "demonstrations, made by one person or more persons, but not more than 15 persons, for or against any person, cause, action or failure to take action". The Act identifies three main actors: the municipality, the South African Police Service and the convener/organiser of the protest who acts either alone or on behalf of a group or organisation. This Act was passed to "regulate the holding of public gatherings and demonstrations at certain places." The Act provides that every person has a right to peaceful demonstration in gatherings with the protection of the police. The Act sets out clear guidelines and procedures on how to conduct public gatherings and how to identify and handle the key players in proposed demonstrations.

The Regulation of Gatherings Act places considerable emphasis and obligations on organisers and conveners of gatherings to comply with all sections of the Act and to take responsible steps to ensure that the gathering occurs in an orderly and peaceful manner. Under section 12 of this Act, the organisers can be held liable for failure to take adequate steps to control participants of 
the gathering and to ensure compliance with all conditions, set out in the approval of the gathering. The Act allows for criminal prosecution of organisers/conveners should they fail to meet their obligations [11] The Act permits the use of force for crowd control when there are apparently "manifest intentions" to kill or to seriously injure persons or to destroy or cause serious property damage. However, the use of force must be necessary, moderate, and proportionate to the circumstances.

The author argues that what we have witnessed in South Africa, recently and over the last 50 years, is the complete failure of protest organisers to control participants, instil discipline and respect for the agreed conditions of the protests, obey the laws of the land on protests, and stop participants, turning up at demonstrations with offensive weapons. We have also noted the failure of the police to hold effective dialogues and negotiate with demonstrators. All these are further exacerbated by the noticeably confrontational style of policing in attempts to control protests to appease politicians. This has led to a further breakdown in the relationship between the police and South African citizens. The killings of protesters have resulted in a build-up of resentment and a lack of trust and confidence in the police. It has also led to a stalemate in community policing in South Africa.

\section{3. The South African Police Service Act 68 of 1995}

Section 13 (3) of the Act provides that "Where a member who performs an official duty is authorised by law to use force, he or she may use only the minimum force, which is reasonable in the circumstances".

Section 17 (chapter 6) of the South African Police Service Act no 68 of 1995 provides that "a public order policing unit shall be established and maintained by the National Police Commissioner who may deploy the national public order policing unit, or ... at the request and in support of Provincial Commissioner" [12].

\section{4. SAPS Standing Order No. 262 on Crowd Management and National Municipal} Policing Standard for Crowd Management

Standing Order No.262 states, clearly and coherently, that the use of force must be avoided at all costs, and members, deployed for the operation, must display the highest degree of tolerance. The use of force and dispersal of crowds must comply with the requirement of sections 8 (1) and (2) of the SAPS Act. The Standing Order further puts in place the procedures to be followed by the police if negotiations fail in a public gathering that exposes lives and property to danger; the Standing Order also prescribes the procedures to be followed by the police if the use of force becomes unavoidable.

\section{5. Basic Principles on the Use of Force and Firearms by Law Enforcement Officials}

The Code of Conduct for Law Enforcement Officials was adopted in 1979 by the General Assembly of the UN.

The Code of Conduct clearly states the following:

Law enforcement officers may use force only when strictly necessary and to the extent, required for the performance of their duty. One can safely argue that the amount of force used needs to be proportionate to the level of threat, faced by police officers. Police officers cannot deploy force without an element of justification for using such force. Firearms can be used only in extremely dangerous situations where the lives of the police or members of the public are endangered. Firearms must not be used against children during demonstrations.

A series of landmark historical events have made a pivotal contribution to our understandings and interpretations of Human Rights as they exist today in South Africa. The era of the Renaissance, the Enlightenment period, the Revolution in France in 1789, and the American War of Independence in 1776 were all highly instrumental in shaping the rights of human and citizens' rights globally. There is widespread agreement among American and European scholars that the last three decades have seen a major transformation in the dominant style of policing [13]. The policing of disorder has become more complex as information technology and modernity have transformed the mobilisation of citizens against the state, represented by the police. Social media have 
produced a very effective means of mobilising protesters. Generally, they have made it difficult for the police to deploy the old, traditional and outdated crowd control management strategies. It has become problematic for the police to accurately predict how many protesters are likely to turn up at demonstrations. Some of the service delivery protests in South Africa have been spontaneous, thus giving the South African Police Service little or no chance to respond adequately to such incidents. The policing of disorder needs a new approach to deal with these new challenges [14]. The researcher will now look at some of the international legal statutes, international laws, and the South African Bill of Rights to support his argument that citizens of South Africa have constitutional rights to protest and, more importantly, a right to life.

A. The Universal Declaration of Human Rights (1948) under Article 20:

1. Everyone has the right to freedom of peaceful assembly and association.

2. No one may be compelled to belong to an association.

Article 23: 4 states:

Everyone has the right to form and to join trade unions.

B. The European Convention on Human Rights (1950) Under Article 2 :

1. Everyone's right to life shall be protected by law. No one shall be deprived of his/her life intentionally, save in the execution of a sentence of a court, following his/her conviction of a crime, for which this penalty is provided by law.

2. Deprivation of life shall not be regarded as inflicted in contravention of this article when it results from the use of force, which is no more than necessary:

a. In defence of any person from unlawful violence;

b. In order to effect a lawful arrest or to prevent the escape of a person, lawfully detained;

c. In action, lawfully taken to quell a riot or insurrection.

Article 11 states:

1. Everyone has the right to freedom of peaceful assembly and to freedom of association with others, including the rights to form and to join trade unions for the protection of his/her interests.

2. No restrictions shall be placed on the exercise of these rights other than such as are prescribed by law and are necessary for a democratic society in the interests of national security or public safety, for the prevention of disorder or crime...

C. The 1996 Constitution (Bill of Rights)

The Bill of Rights is the cornerstone of democracy in South Africa. It enshrines the rights of all people, living in the Republic of South Africa. It affirms and reaffirms the democratic values of human dignity, equality, and freedom.

Section 11 states that everyone has the right to life.

The right to life is considered by many researchers to be the most important of human rights because, without life, all other existing rights cannot be enjoyed. Citizens' right to life must be protected by the police rather than unlawfully taken during demonstrations. A life taken cannot be restored, regardless of whether it was taken accidentally or intentionally. Police officers should protect the lives of citizens rather than deploying firearms to kill protesters. The researcher argues that no amount of justification would excuse the misdeeds of a police officer who had sworn under his/her oath of office to protect and serve citizens of South Africa, as such cases might be turned around after unfortunate incidents to justify such killings. The researcher argues that the police have always given the public several excuses, ranging from provocation, self-defense, and evading or resisting arrest to accidental discharge of firearms.

Section 17 of the 1996 Constitution states the following:

Everyone has the right, peacefully and unarmed, to assemble, to demonstrate, to picket, and to present petitions. The researcher has observed that protesters in South Africa are accustomed to carrying offensive weapons, such as sticks, clubs, and traditional weapons that are sometimes used to inflict injuries on the police. The police, in retaliation, deploy heavy-handedness and brutality, fearing for their safety. Some protesters carry firearms to demonstrations and shoot at the police. Generally, the carrying of any kind of weapons during public demonstrations is illegal and invalidates the claim to peaceful protest, which the South African Constitution allows. Waddington [13], 
in Policing Disorder, argues that "what police officers want from the academic analysis is not a manual of how to fight battles on the streets - they know that well enough. Instead, they want and need a wider understanding of why disorder erupts at all and with what consequences... the dynamic potential of crowds must be acknowledged and the possible impact of policy and other action on this dynamic process must be appreciated in order to arrive at a workable solution to the problem of controlling public disorder". In other to understand the dynamics of collective social behaviour, resulting from public disorder, the researcher relied on the work of two theorists, Lebon [15] and Smelser [16].

Lebon's major work, "The crowd: a study of the popular mind" explains that whenever people form crowds, their conscious personalities automatically disappear to be replaced by a sinister, uncivilized and potentially barbaric group mind. There are three reasons for this. First, the anonymity, deriving from crowd membership, separates individuals from any personal responsibility for their actions. Second, being part of a crowd makes people less resistant to "hypnotic" powers of suggestion that may compel them to behave in reckless and unsavoury ways, Third, crowd behaviour and the powerful emotions it evokes tend to spread contagiously, causing virtually everyone present to recklessly join in.

Smelser identified five determining factors, contributing to public disorder:

- structural conduciveness;

- structural strain;

- the growth and spread of generalised hostile belief;

- precipitatory factors;

- the mobilisation of participants for action and social control.

The author argues that protesters feel some sense of security when gathered in large numbers and when the "us and them" factor comes into play [17].

The police have always been seen as agents and apparatus of the state, created to oppress marginalised classes in society. This is true to some extent because the police treat members of society differently and tend to be harsher on unemployed, deprived, and poor citizens.

Aim of research was to identify and address some of the challenges, faced by police officers during public protests, and to reduce loss of lives during public protests

\section{Materials and Methods}

The author uses a qualitative approach, relying on previous existing works of literature, relating to the research topic "public order policing". Collected data were analysed manually using a thematic coding process. Themes were arranged consistent with related concepts, grouped into one after the other. The author consulted secondary sources in order to have a broaden knowledge of the research topic. Books, academic peer-review journals, official reports, media reports, newspapers, and internet sources were all consulted. The author has practical knowledge of public order policing as he was trained by the British police. The author epitomises an example of where a person has the practical experience and the theoretical knowledge to conceptualise the research topic.

\section{Result}

\section{1. Evidence of Violations of Citizens' Right to Protest in South Africa}

The researcher argues that it is problematic in trying to estimate the total number of incidents where the human rights of South Africans citizens have been violated by the police and law enforcement agents during protest. First, not all incidents are reported to the police. Many incidents go unreported for several reasons, such as fear of reprisals, victims' feeling they would not be believed, stigma, economic factors, safety issues, and cases where the perpetrators are one's relatives. In this section, the researcher will mention just a few of the incidents, in which the police have contributed to violations of citizens' rights during the apartheid and post-apartheid eras.

24 May 1921: President Smuts' Government ordered the police into a black residential area in Ntabelangu near Bulhoek where people were protesting against squatting evictions. 100 black people were killed and 100 more were wounded. 
May 1922: In a mineworker's strike, 129 soldiers and policemen, 43 civilians, and 39 miners were killed.

12 August 1946: 9 miners were killed by the police.

27 March 1950: 14 people were killed by the South African Police in Wiziehoek, Orange Free State, for protesting against livestock farming.

1 May 1950: 18 protesters were killed by the police in Alexandria and surrounding areas during a general strike against discriminatory laws.

21 March 1960: 69 blacks were killed by the police in Sharpeville station near Vereeniging. They were protesting against repressive pass laws. This incident is referred to as the Sharpeville Massacre. It showed the world the dark side of the apartheid regime. It also led to worldwide condemnation of the South Africa government, which was becoming more isolated from the rest of the world. The UN passed Resolution 134, calling for sanctions against South Africa. It led to the birth of Umkonto we Sizwe, the armed wing of the ANC, which adopted an armed struggle against the regime.

17 June 1980: 25 pupils were killed by the police during a school boycott in Elsies River near Cape Town.

September 1984: 26 protesters were killed by the police in Vaal Triangle during protests against rent increases.

18-19 February 1985: 18 protesters were killed by the police in Crossroads, Cape Town, during the construction of the new township in Khayelitsha.

21 March 1985: 20 people were killed by the police during the $25^{\text {th }}$ anniversary of the Sharpeville Massacre between Uitenhage and KwaNobhle.

5-14 August 1985: 70 people were killed by the Amabutho (IFP regiments) police in Kwazulu Natal over politically motivated rivalries.

11 August 1985: 23 people were killed in Duncan Village, East London, in Eastern Cape.

28-31 August 1985: 31 people were killed by the police during a 'Free Mandela' march.

18 November 1985: 14 people were killed by the police in Queenstown, Eastern Cape.

17-26 May 1986: 44 people were killed by the police in Witdocke, in Cape Town squatters' camps.

20-25 May 1986: 11 people were killed in Kwamashu near Durban by the Amabutho IFP regiment police.

26-27 July 1986: 24 demonstrators were killed by the police in White City, Soweto. The protests were caused by a rent boycott.

12 January 1991: 45 African National Congress (ANC) members were killed in Sebokeng allegedly by IFP in collusion with the police while attending a funeral.

17 June 1991: 46 people were killed by IFP in Boipatong near Vereeniging.

2011: Andries Tatane was killed during a poor service delivery protest in Ficksburg Free State. The case of the killing of Tatane was brought before the South African Human Rights Court where it was held, that Tatane had been unlawfully killed and that his right to protest, right to life, and right to respect and dignity, enshrined in the Bill of Rights, had all been violated. The court ruled as follows:

- The police should improve the training of police officers in managing and regulating gatherings to ensure that future policy interventions in public protests result in a more peaceful and non-violent outcome.

- The police should develop a training manual for the Public Riot Units together with the Commission Advocacy Programme. The police should focus more on training their Public Riot Units.

- The police should engage in communication with communities where there are popular protests.

- The Minister of Police and the Minister of Cooperative Governance and Traditional Affairs should report jointly every six months, detailing all the measures, put in place to address the phenomenon of increasingly violent community protests.

16 August 2012: 34 miners were killed by the police during mining strikes by workers at Lonmin plant near Rustenburg. This was the first mass killing by the police since 1994. It brought 
back bad memories of the past when killings by the police were more frequent. The ANC-led government set up an Inquiry to investigate these killings; this Inquiry was headed by Justice Ian Farlam [4].

The investigation was ongoing during the time of writing this article. However, a few disturbing things have emerged from the Inquiry so far:

- It was alleged, that the ANC deputy leader Mr Cyril Ramaphosa exerted political pressure on the police to act, calling protesters criminals. It is also alleged, that Ramaphosa has business interests at Lonmin. Should these allegations turn out to be true, Ramaphosa's credentials as a freedom fighter would be dented by his decision to put his business interests before the lives of the miners.

- It has also emerged, that the police shot at miners who were fleeing the scene, contrary to the earlier police version of events that the 34 miners who were killed were very hostile and confrontational towards the police.

- The number of rounds of ammunition, used by the police, suggests premeditated and intentional killings.

- The big unanswered questions are as follows: Was the force, used by the South African Police Service at Marikana, lawful or unlawful? Was it reasonable and proportionate?

- What sanctions will be applied to police officers if found guilty of murder?

The National Police Commissioner, Riah Phiyega, praised and lauded police officers in public just a few hours after the senseless killings; she stated that the police did the right thing by serving their country in the best possible way. Some South Africans took offence at such a statement, justifying the killings, and it brought back old memories of the ruthless apartheid regime when lives were wasted and regarded as meaningless by state officials. [18].

The author argues that the killing of protesters has escalated in 2014.

- In January 2014 alone, seven protesters were killed by the police in South Africa. Four were killed in Relela and Kubjana near Tzaneen.

- Tshepo Babuseng, aged 28, was shot dead by police in Durban Deep Roodepoort Guateng during service delivery protests.

- In Mothuthulung, another three protesters were killed by the police during a service delivery protest when water supplies to residents were cut off.

The author meticulously followed some of the work of Andrew Faull [19], Fighting for Respect: Violence, masculinity and legitimacy in the SAPS. Faull elucidated further on SAPS's logic of violence. He argues as follows:

"Many embrace an underlying logic that says the state allows police the use of force because force and violence prevent crime. This logic suggests that if police are forceful enough, civilians will, out of fear, respect the state, and South Africa will be at peace". The author agrees with the three reasons, identified by Faull [19] as to why the police logic of violence is deeply flawed and bound to fail in the long term. First, we claim to live in a democratic country where there is the rule of law and citizens have rights. If this is true, violence by the police will face challenges from citizens because they will eventually become more aware of their rights and will know what to do when these rights are violated. Second, although the dark side of the police and what goes on out of the public view is not always pleasant, police officers do not turn a blind eye by choice but because they have been made to subscribe to the pervasive police culture and solidarity. There is a huge risk of isolation and, in some cases, personal danger, if one breaks the code of silence [20-23]. Third, effective and responsive policing is not built on fear alone but on consent and the ability to successfully investigate. The police need the support of all members of the communities they serve and protect. Robert Peel, one of the founding fathers of modern British policing, was very clear about the importance of "policing by consent". In today's South Africa, the problematic relationship between the police and citizens who live in perpetual fear is counterproductive in fighting crime and making our communities safer. Next, the author explores how the disorder is policed in the United Kingdom.

\section{2. Policing Disorder in the United Kingdom}

The United Kingdom has witnessed several violent protests, in which the British police have had to face the challenges of urban protests and public expectations. The author will refer 
to the following riots and demonstrations that have occurred over the last 60 years in Britain: the Nottingham and Noting Hill Race Riots of 1958, the Brixton Riots of 1981 resulting from black Londoners protesting over continuous police harassment using stop and search policies [24], the Miners' Strike of the 1980s, the Poll Tax Riots of 1990, and the Broadwater Farm Riots in Tottenham in 1985, which resulted in the murder of Police Constable Blakelock. The author attended a police training school in the UK in 1997, when video footage of PC Blakelock's death was shown to the whole class. First, it became clear that during riots anyone can be killed, as people no longer think rationally; a spontaneous breakdown in the process of law and order becomes inevitable and in most cases, it is very difficult to restore order when adrenalin is high and the "red mist" clouds professional judgment. Second, seeing how PC Blakelock was hacked to death by the rioters made the researcher grasp the reality of policing disorder. Third, most riots are guided by irrational choices: "kill or you get killed." The researcher argues from his experience of receiving training in dealing with public order. First, an angry mob is often unpredictable. Second, the policing of disorder needs some element of flexibility in police tactics. Third, intelligence reports on demonstrators are not always $100 \%$ reliable. The British police are very good at driving home these points; i.e. policing is a very risky job and all officers should be prepared to pay the highest price in performing their duty at all times.

The original British model of policing was designed to be adaptable to ensure the safety of the public and the preservation of the peace, and it has shown itself to be effective in the use of large-scale containment during the central London disturbances of May Day 2001, and the greater use of proactive communication after the G20 protests of 2009. "Public Order policing can adapt dynamically to changing times through the right balance of officer training, tactics, confidence, command and accessible guidance" $[25,26]$. The British Police are guided by public order policing documents, such as "Keeping the Peace", formulated by the Association of Chief Constables in October 2011.

\section{3. Containment or Kettling}

The author argues that the concept of containment or kettling is something new to the policing of disorder in the UK and that "mass containment tactics developed as a result of the Para-militarization of protests in the 1980s and 1990s" [27]. Police in the UK have to adapt their public order strategies to "containing disorderly gatherings within tight but essentially static cordons" [28]. The strategy works on the simple principle that police officers are in physical contact with the outer circle of contained protesters. Those in the centre are surrounded by other protesters and therefore effectively self-policed, assuming that protesters do not turn on one another [29]. After a series of legal challenges to the police, claiming that containment was unlawful and an abuse of human rights, especially freedom of movement (as some protesters were denied access to toilets during protest marches), and that the right to assembly had been violated as a result of such denial, the UK court finally ruled in 2005 that containment during a public protest is lawful [30]. Next, the author explores how the disorder is policed in Canada.

\section{4. Policing Disorder in Canada}

W. de Lint [31] argues that in Canada there has historically been a low tolerance to public disorder and strong support for government use of coercion in the maintenance of public order, even at the expense of civil liberties. This line of argument is supported by Yesufu [17, 32]. A case in point occurred on September $6^{\text {th, }} 1995$, when an Ontario Provincial Police sniper shot and fatally wounded an unarmed indigenous man, Dudley George, after police moved to forcibly end a land rights protest at Ipperwash Provincial Park. On two occasions, in 2007 and 2008, the OPP responded to protests over a longstanding land claim in the Tyendinaga Mohawk Territory near Bellevile by mobilising the Tactics and Rescue Unit, commonly known as the sniper squad. There is evidence to suggest that unlawful lethal weapons were used against demonstrators [33].

Yesufu \& Motsepe [34] argues that "police forces are considering standardizing public order units and responses to major events, swapping information and experiences on reconciling Charter rights with public peace and dealing with the financial impact of the burgeoning disorder." With 
reference to the G20 protest in Toronto, it was found, that police "violated civil rights, overstepped authority, detained people illegally and used excessive force" [34].

W. de Lint [31] introduces us to three concepts of order production: the politics of law, the politics of enforcement, and the politics of consent. Collectively, they help us to understand the dynamics and complexities of maintaining law and order.

* The politics of law refers to the legitimacy of rule-making or the legislative function. Is the law-making function well-grounded constitutionally, representative, and well-founded in liberal democratic values?

* The politics of consent refers to the legitimacy of rule-following or the value of strong compliance with the polity. The orientation may be more or less consensual; i.e. the politico-legal environment may reinforce the relationship between institutions and individuals.

* The politics of enforcement refers to the legitimacy of the enforcement function. Is enforcement of law more or less integrative? Is it carried out according to liberal democratic values, respecting constitutional rights and freedoms? Is it reflective of best practices, representative of the polity, and effective in its mandate to diffuse disorder or political disintegration?

The author argues that, in evaluating the South African Police Service today, one can safely say that it does not currently meet any of the three concepts of order production, enumerated above by W. de Lint. This does not mean that they are not achievable; it is possible to achieve these standards for the policing of disorder in South Africa through the coordinated training of police officers. In Canada, the policing of the disorder tends to involve officers, deploying the use of effective communication skills, persuasive enough to encourage protesters to enter into dialogue and negotiations. In brief, the best methods of policing protests are encapsulated in three best practices: recognising politics, facilitating communication, and defusing violence.

W. de Lint [31] concludes that Canada has developed over the years a hybrid police form, in which control and service are practised simultaneously in a morphing of intelligence-led and community policing orientations $[32,35]$.

Canada has several well-trained police departments, dealing with public disorder. The researcher presents some of these departments as follows: Dominion Police, Northwest Mounted Police, Ontario Provincial Police, the British Columbia Police, and the Royal Canadian Mounted police, who was instrumental in quelling the general strike of 1919 in Winnipeg. The same force (RCMP) was called in to deal with public disorder on July 111990 in Quebec, where they successfully dealt with a 78-day stand-off known in the history of Canada as the "OKA Crisis in Quebec".

First, the author wishes to draw the reader's attention to the "78 days", as I am not sure whether members of the South African Police would be able to persevere for this length of time. The whole approach of confronting protests and quelling them as quickly as possible by using excessive force has cost so many lives in South Africa. The police need to change their tactics by forming more tolerant public order units to deal with protests. Second, looking at how the police deal with disorder in Canada, one can say that the number of deaths during protests is reduced to the barest minimum; the South African Police Service should study this carefully to determine whether this model might be compatible with the demographics of South Africa. Next, the author looks at some of the challenges to policing disorder as follows:

\section{5. Public Policing Challenges}

A. Police Culture (cult of machismo)

Monique Mark's [36] research into the closed world of the South African police provides us with some interesting revelations. She argues that townships have remained one of the areas where oppressive policing and brutality are more likely to happen. On one of her trips, she witnessed the use of force and a catalogue of violations of due process and basic human rights of citizens. When she queried the use of violence, one officer responded that "these people" (township residents) only understood force and those hard-hitting tactics were required, if the police were to be effective.

The author argues that the cult of machismo encourages a culture of violence to flourish unabated, resulting in the mistreatment of prisoners and insensitivity to people's feelings. The abuse of police powers becomes routine because victims are mostly too afraid to make complaints, 
and even if they eventually do, most of the complaints are unlikely to be substantiated. The cult of machismo encourages police officers to close ranks and turn a blind eye when their colleagues break the law. It promotes a code of silence. Previous researchers have called this act of silence "solidarity" and "closing ranks" $([21,22]$ who have written extensively on police culture and its effects on policing and victims of crime). Some researchers have argued that the exigencies of police work have made some of them less sensitive to human feelings and cause them to close ranks when faced with potential threats from outsiders [23]. It is the police culture that makes police officers selective about which jobs they consider "real policing". "Real" police work is full of excitement and the display of bravado, where officers are socialised into the police cult of masculinity. The police culture encourages male police officers to disrespect their female colleagues, cynically questioning their ability to police [23].

B. Inadequate public order policing training

This issue was highlighted by the police killing of 34 miners at Marikana in 2012. The deployment of public order policing (POP) was poorly planned and commanded. As a result, the use of less lethal weapons was ineffective and in some incidence, the sight of the POP escalated the tension instead of reducing it. The SAPS intervention at Marikana was unique. It mobilised a formidable part of the SAPS capability to use force for an unfamiliar task. None of the units deployed had any experience in disarming large and potentially hostile groups of people or had the experience of carrying out such joint interventions [37].

C. Ineffective communication

At Marikana, the SAPS had no single and coordinated approach to crowd management. They entered the scene without carrying out a proper risk assessment with different stakeholders, negotiators were inexperienced [17]. During the mayhem, protesters could not be easy be selected by the police.

D. Excessive use of a lethal weapon

The SAPS deployed the use of the R5 rifles. This is a very high-velocity automatic rifle. The author believes that such firearms should not be used for public crown management.

E. Failure to demilitarised the South African Police Service

There has been a call for the SAPS to be completely demilitarized and to becoming have a service commitment to citizens. The National Development Plan 2030, called for a professional service and the complete demilitarisation of SAPS (Western Cape Government, 2018). After 20 years of this call, it has fallen on deaf ears by each successive government.

F. Failure of the government to provide service delivery to citizens

Some of the public protests in South Africa are resulting from the government's inability to meet the basic needs of citizens. The government in some instances is not able to provide housing, employment, education, and health to its citizens. The extent of protests in South Africa underscores the underlying communities' frustrations with an option to resort to violence rather than non-violent protests. One of the frightening aspects of the wave of protests is undoubtedly the seriousness of the violence that is evident during the protests. Some protests result in the loss of lives, billions of rand in damages to public buildings, the exhaustive use of police resources for crowd control, and the disruption of everyday activities. The responsibility of policing and managing disorderly protests is challenging and subsequently left to the over-strained Public Order Police.

\section{Future Directions: Best Practice in the Policing of Disorder}

One of the policy documents, published by the South Africa Ministry of Police (2012) entitled Policy and Guidelines: Policing of Public Protest, Gatherings and Major Events, sets out evidence of good police practice concerning the policing of disorder. The scope and objectives of the policy were listed as follows:

The policy aims to provide a framework with guidelines for the SAPS in reviewing and aligning its operational strategies and instructions, applicable to the policing of public protests and related major events to minimize provocation, intimidation, and violence.

Objectives are as follows:

- Promote crowd control and management capacity within the police to secure public trust and maintenance of safety during public gatherings. 
- Establish the principle of intervention in controlling public protests to determine the proportionate means of force that can be applied by the police.

- Facilitate the introduction of appropriate training initiatives, which must, among others, address the principle of "first responder" and guide SAPS operational planning and response, resource deployment, and physical execution.

The author argues that none of these laudable objectives seem to have been followed during the Marikana massacre in 2012 when 34 miners were allegedly gunned down by the police who opened fire on them during a protest at the Lonmin Mining plant near Rustenburg. These objectives were again not followed in 2014, as it has been widely reported, that seven protesters have so far been killed in South Africa in January alone. The author argues that it has become imperative for the SAPS to review its current public order policing as a matter of urgency as the current one does not appear to be working. There are far fewer casualties in the United Kingdom and Canada than in South Africa. In some countries, there are far more protesters than in South Africa. Consider, for example, the Poll Tax demonstrations in London in 1990. How are the British police able to control protests effectively without them resulting in a high death toll? Next, the author provides the reader a list of recommendations for public order policing improvement in South Africa. They are as follows:

- The South Africa government must ensure that service delivery must involve engaging with communities and stakeholders to influence disgruntled groups and provide a forum for hearing and providing solutions to citizens (Institute for Security Studies, 2017).

- Greater accountability both within the governance of the SAPS and all other members.

- The Establishment of a National Policing Board to ensuring the use of force by police complies with the rule of law, human rights principles, and international law.

- There should be no carrying of any weapon by protesters, this is consistent with section 17 of the Constitution, no person has a constitutionally protected right to carry arms during public protests'.

- The immediate demilitarisation of the South African Police Service. Only the firearms unit will allow carrying firearms

\section{Conclusion}

The author provides us with some insight into the procedural justice theory and draws the following conclusions. First, the police should educate themselves concerning the social identities of the crowds, including their values and legitimate aims. Second, legitimate collective aims should be facilitated, not hindered. Third, police should communicate their intention to facilitate the right to protest. Finally, the police must differentiate between individuals and groups and avoid indiscriminate force. However, there is a need to separate genuine protesters from the criminal elements of society who attempt to hide behind genuine protesters to commit unlawful acts of violence. Sometimes, in operational and volatile situations, it is very difficult for the police to distinguish between the two types of protesters.

The author would like to see the South African Police Service review its public order policing methods, crowd control management, and the use of force during protests as a matter of urgency. Police officers should be properly trained and equipped to police disorder effectively. Police officers should not be allowed to shoot and kill rioters in any democratic country. The researcher argues that citizens should strive within the confines of the law to bring to an end these unlawful killings by the police during public protests, as the right to demonstrate is a constitutional right, enshrined in the South Africa Bill of Rights. The South African government must send a clear message to the police that the killing of innocent citizens will no longer be condoned and that those who kill in the name of the law will be made to face the same law they have sworn to defend.

Finally, the author observes that, within the last decade in South Africa, two schools of thought have emerged within the academic discourse on policing. The first school of thought, which researchers term "conservative", comprises those who often subscribe to the study of policing in South Africa in isolation; they are informed by the mind-set that there is nothing to learn from the outside world, are more likely to mount a resistance to change and are more hostile to 
foreign education or international standards. This school of thought holds that knowledge is a static thing that cannot be transferred from one country to another. This conservative school of thought has managed to hold on to some of the old order of the apartheid days when the educational system in South Africa was run on racialist principles. This was an era when the type of education one received was based on the colour of one's skin and not on individual abilities. The second school of thought consists of the "progressives", who would simply agree that there is something wrong with policing in South Africa but are not sure which foreign policing model to adopt to reduce the high numbers of deaths, caused by excessive use of force, or how to improve crime and criminal investigations, forensics and DNA profiling (see South African Government Ministry of Policing 2012 and the South African Government Green Paper on Policing [11]. The researcher concludes that the South African Police Service needs assistance in order to police disorder effectively, reduce the number of deaths, resulting from the use of excessive force and lethal weapons, and increase the level of communication between protesters, organisers, and the police. The organisers of protesters should be held accountable when their members turn up at demonstrations fully armed. Demonstrations should not be seen as a war zone or an opportunity for settling old scores with society, the government, or the police. They should be seen as a means for the citizen to exercise his/her democratic and inalienable rights. Protesters who attend demonstrations armed with clubs, sticks, knives, guns, and other offensive weapons should be treated as criminals when arrested by the police. Protestors who arm themselves with weapons risk forfeiting their constitutional rights. In the same vein, police officers who kill unlawfully during protests should be brought before the courts to face charges.

\section{References}

[1] Omar, B. (2007). Costly restructuring review of public order policing capacity. Institute for Security Studies. Monograph 138.

[2] Ncube, G. (2014). South Africa's police versus South Africa's civilians. Africa Conflict Monthly Monitor, 55.

[3] Nicolson, G. (2017). Marikana what has been done on SAPS recommendations? Daily Maverick.

[4] Farlam, I., Hemraj, P. D., Tokota, B. R. (2015). Marikana Commission of Inquiry: Report on Matters of Public National and International Concern Arising out of the Tragic Incidents at the Lonmin Mine in Marikana, in the North West Province.

[5] Nhlabathi, H. (2013). Marikana Muti Magic Allegations. Times Live.

[6] Sosibo, K. (2013). Marikana: Suicide on the Koppie. Mail \& Guardian.

[7] Von Holdt, K. (2013). South Africa: the transition to violent democracy. Review of African Political Economy, 40 (138), 589-604. doi: http://doi.org/10.1080/03056244.2013.854040

[8] Lancaster, 1. (2016). At the Heart of Discontent: Measuring Public violence in South Africa. Pretoria. Institute for Security Studies.

[9] Langa, M., Bowman, B. (2017). The Drivers of Violence in South Africa: Current Knowledge, Community-Level Differences and New Possibilities for Advancing Violence Prevention Scholarship. Johannesburg: Center for the Study of Violence and Reconciliation.

[10] Leggett, T. (2005). Just Another Miracle: A Decade of Crime and Justice In Democratic South Africa. Social Research, $72(3), 581-604$.

[11] South African Government Green Paper on Policing (2012). Pretoria: The office of Police Secretariat.

[12] South African Police Service (SAPS). Available at: https://www.saps.gov.za Last accessed: 26.06.2021

[13] Waddington. P. A. J.; Newburn, T. (Ed.) (2003). Policing Public Disorder and Political Contention. Handbook of Policing. Cullumpton: Wilan.

[14] Reicher, S., Stott, C., Cronin, P., Adang, O. (2004). An integrated approach to crowd psychology and public order policing. Policing: An International Journal of Police Strategies \& Management, 27 (4), 558-572. doi: http://doi.org/10.1108/13639510410566271

[15] Le Bon, G. (1895). The Crowd: A Study of the Popular Mind. New York: Macmillan. Available at: https://www.files.ethz.ch/ isn/125518/1414_LeBon.pdf

[16] Smelser, N.; Smelser, N. (Ed.) (1967). Social and Psychological Dimensions of collective behaviour. Essays in sociological explanation. Prentice-Hall: Englewood Cliffs.

[17] Yesufu, S. (2017). The Reality of Crime and Policing in the United Kingdom and South Africa. Cape Town. Reach Publishers.

[18] Sahistory. Available at: http://www.sahistory.org Last accessed: 11.05.2021

[19] Faull, A. (2013). Fighting for respect: Violence, masculinity and legitimacy in the SAPS. South African Crime Quarterly, 44. doi: http://doi.org/10.17159/2413-3108/2013/v0i44a817 
[20] Holdaway, S. (1983). Inside the British Police. London: Blackwell, 186.

[21] Chan, J. B. L. (1997). Changing Police Culture: Policing in a Multicultural society. Cambridge University Press, 267.

[22] Loftus, B. (2009). Police Culture in a Changing World. London: Clarendon Press, 240.

[23] Reiner, R. (2010). The Politics of the Police. Oxford: Oxford University Press, 70.

[24] Scarman, L. (1981). The Brixton Disorders. London: HMSO.

[25] Noakes, J. A., Klocke, B. V., Gillham, P. F. (2005). Whose Streets? Police and Protester Struggles over Space in Washington, DC, 29-30 September 2001. Policing and Society, 15 (3), 235-254. doi: http://doi.org/10.1080/10439460500168576

[26] Adapting to Protest, HMIC (2009). Her Majesty's Chief Inspectorate of Constabulary (HMIC).

[27] Mawby, R.; Newburn, T. (Ed.) (2008). Models of Policing. Handbook of Policing. Cullompton: Willan Publishing. doi: http:// doi.org/10.4324/9780203118238.ch2

[28] Waddington, P., Wright, M.; Newburn, T. (Ed.) (2008). Police Use of Force, firearms and riot-control. Handbook of Policing. Cullumpton: Wilan Publishing. doi: http://doi.org/10.4324/9780203118238.ch18

[29] Murray, H. M. (2010). Police Legitimacy and Policing Public Protest, Working Paper Series No 2010/36. doi: http://doi.org/ $10.2139 /$ ssrn. 1709401

[30] Hoggett, J., Stott, C. (2010). The role of crowd theory in determining the use of force in public order policing. Policing and Society, 20 (2), 223-236. doi: http://doi.org/10.1080/10439461003668468

[31] De Lint, W. (2005). Public order policing: A tough act to follow? International Journal of the Sociology of Law, 33 (4), $179-199$. doi: http://doi.org/10.1016/j.ijs1.2005.08.001

[32] King, M. (2006). From reactive policing to crowd management? Policing anti-globalization protest in Canada. Jurisprudencija, 1 (79), 40-58.

[33] Amnesty. Available at: https://www.amnesty.org/en/ Last accessed: 15.04.2021

[34] Yesufu, S., Motsepe, L. L. (2020). Reflections on the Capacity of policing Community Policing Protests: A South African Perspective. International Journal of Social Sciences and Humanities Studies, 12 (2), $482-497$.

[35] Baxter, N. (2001). Policing the line: the development of a theoretical model for the policing of conflict. Dartmouth: Ashgate, 324.

[36] Marks, M. (2003). Shifting Gears or Slamming the Brakes? A Review of Police Behavioural Change in a Post-Apartheid Police Unit. Policing and Society, 13 (3), 235-258. doi: http://doi.org/10.1080/10439460308031

[37] Bruce, D. (2017). Commissioner and Commanders. Police leadership and the Marikana Massacre. Pretoria. ISS Monograph Number 194. Institute for Security Studies.

How to cite. Yesufu, S. (2021). Human rights and the policing of disorder in South Africa: challenges and future directions. EUREKA: Social and Humanities, 3, 72-84. doi: http://doi.org/10.21303/2504-5571.2021.001861 